\title{
AN EXPERIMENTAL INVESTIGATION ON THE EFFECT OF INDUCTION FURNACE SLAG AS FULL REPLACEMENT OF FINE AGGREGATE AND PARTIAL REPLACEMENT OF COARSE AGGREGATE IN M25 GRADE CONCRETE
}

\author{
Y. Mahendra \\ Postgraduate Student, Department of \\ Civil Engineering, VITAM College of \\ Engineering, Mindivanipalem (V), \\ Sontyam (P), Anandapuram (M), \\ Visakhapatnam-531173, \\ Andhra Pradesh, India.
}

\author{
Mr. B. Siva Prasad \\ Assistant Professor, Department of Civil \\ Engineering, VITAM College of \\ Engineering, Midivanipalem (V), Sontyam \\ (P), Anandapuram (M), \\ Visakhapatnam-531173, \\ Andhra Pradesh, India.
}

Abstract -- The environmental problems are very common due to generation of industrial byproducts. The industrial produce and utilization of these by-products is the main challenge faced in India. Induction Furnace Slag is one of the industrial by-product from steel and iron manufacturing industries. Hence, here an attempt has been made to assess the possibility of using an industrial furnace slag as a full replacement in fine aggregate and partial replacement in coarse aggregate. Induction furnace slag is used as replacement of fine and coarse aggregate on criteria of particle size after performing sieve analysis using Indian Standards and has been physically and chemically characterized. Induction furnace slag is replaced in coarse aggregate in the range of $0 \%, 5 \%, 10 \%, 15 \%$ and $20 \%$ by weight and $100 \%$ replacement in fine aggregate in concrete for $\mathrm{M} 25$ grade concrete is used for a W/C ratio 0.62. The test performed to evaluate induction furnace slag concrete quality include slump cone test, compressive strength test, split tensile strength test and flexural strength test. Cubes, cylinders and prisms are casted and tested for 3 , 7, and 28 days. The results shows that as increment of induction furnace slag percentage improve the hardened properties progressively up to $15 \%$ of induction furnace slag is replaced in coarse aggregate and starts decreases after
$15 \%$ of IFS is replaced in coarse aggregate for compressive strength, split tensile strength and flexural strength.

Keywords - Induction furnace slag (IFS), M25 grade concrete, Compressive strength, Split tensile strength, Flexural strength.

\section{INTRODUCTION}

Concrete is primarily comprised of Portland cement, aggregates, and water. Although the Portland cement typically comprises only $12 \%$ of the concrete mass, still it accounts for approximately $93 \%$ of the total embodied energy of concrete. Some remedial measures can be taken to minimize some better properties of concrete. In the process of cast iron and ductile iron production, secondary raw material and Industrial wastes are formed. The most abundant waste originating in the process is induction furnace slag. Slags are compounds of oxides of metal \& nonmetallic elements which form chemical compounds and solutions with each other and also contain small volume of metals, sulfides of metal and gases. This slag is disposed of the factory floor due to which land contamination takes place which decrease fertility of soil. Induction furnace slag contain about $10-15 \%$ metal. 


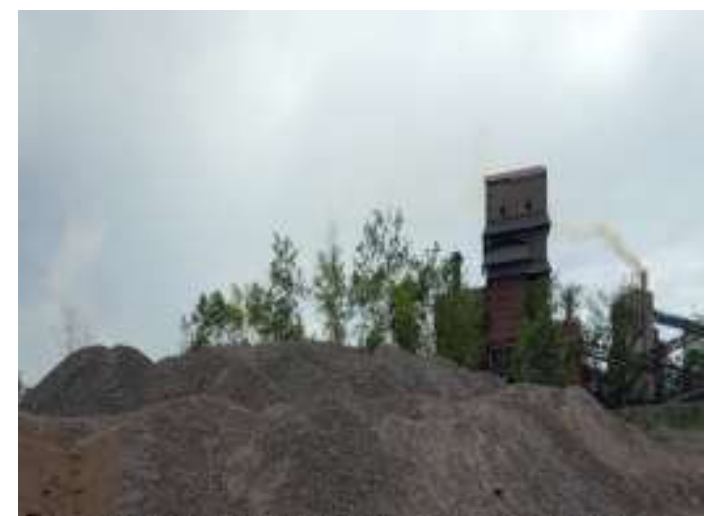

Fig 1 IFS at MAA MAHA MAYA INDUSTRIES

Concrete is a composite material, it is a mixture of cement, fine aggregate, coarse aggregate and water. In this investigation the Induction furnace slag was replaced in fine aggregate and coarse aggregate with different proportions. The present investigation has been done based on the following objectives.

- The target for the present work is to design a concrete mix which would reduce the cost of construction and cost of ingredients of concrete.

- To study the feasibility of attaining the strength with Ordinary Portland cement and induction furnace slag.

- To minimize the natural resources such as sand and crushed aggregates by replacing with Induction furnace slag.

\section{LITERATURE REVIEW}

Syed Istiaq Ahmad and Md. Shafiqur Rahman [2018] were studied the mechanical and durability properties of Induction-Furnace-Slag-Incorporated recycled aggregate concrete. The Recycled coarse aggregate was replaced with induction furnace slag by $0 \%, 25 \%, 50 \%, 75 \%$, and $100 \%$ for each target strength. For up to $50 \%$ of induction furnace slag replacement, both compressive strength and split tensile strength increased in recycled aggregate concrete.

Kr. Ramsudar and R. Jayanthi [2018] in this experimental investigation the partial replacement of fine aggregate waste iron slag were reused to partially replacement of $0 \%, 10 \%, 20 \%$ and $30 \%$ of sand weight. The maximum strength of compressive strength and split tensile strength was found to be at $30 \%$ of steel slag.

U Mohammed et al. [2017] were conducted an experimental investigation was carried out to explore the suitability of utilizing induction furnace slag as coarse aggregate in concrete. The concrete specimens were tested at 7, 28 and 90 days. Based on results, the optimum replacement ratio of brick aggregate by induction furnace slag aggregate with respect to compressive strength and tensile strength of concrete is found at $50 \%$.

Anil et al. [2017] were conducted an experimental study on effect of steel slag as partial replacement of fine aggregate in M35 grade concrete. The fine aggregate was replaced with steel slag by $0 \%, 11 \%$, $22 \%, 33 \%$, and $44 \%$ (by weight) for each target strength. Based on results, the optimum value of compressive strength, flexural strength, split tensile strength can be achieved by $33 \%$ replacement of steel slag.

M. A. Qurishee et al. [2016] were conducted a study on use of slag as coarse aggregate and its effect on mechanical properties of concrete. The proportion of stone chips and slag used in this investigation as coarse aggregate are 0 to $100 \%$. Concrete made by replacing coarse aggregate with BFS is observed to increase up to a replacement level of $40 \%$.

\section{EXPERIMENTAL INVESTIGATION}

Experimental investigation were carried out on the various types of ingredients of concrete. Details of the material used, methodology of various tests conducted during investigation are as below.

\section{A. Material used - \\ Cement \\ Ordinary Portland cement of 53 grade conforming to Indian standard IS: $12269-1987$ was used for the present experimental investigation. Various properties of cement were determined as per IS4031 (1988) and the results are given in Table 1.}

Table 1 Properties of Cement

\begin{tabular}{|l|l|l|}
\hline \multicolumn{1}{|c|}{ Property } & Result & $\begin{array}{l}\text { Requirements of } \\
\text { IS 12267-1987 }\end{array}$ \\
\hline Fineness of cement & $5.8 \%$ & $\begin{array}{l}\text { Not more than } \\
10 \%\end{array}$ \\
\hline Normal consistency & $31 \%$ & \multicolumn{1}{|c|}{-} \\
\hline Specific gravity & 3.07 & \multicolumn{1}{|c|}{-} \\
\hline Initial setting time & $45 \mathrm{~min}$ & $\begin{array}{l}\text { Should not be less } \\
\text { than 30 min }\end{array}$ \\
\hline Final setting time & $\begin{array}{l}480 \\
\text { min }\end{array}$ & $\begin{array}{l}\text { Should not be } \\
\text { more than 600 min }\end{array}$ \\
\hline $\begin{array}{l}\text { Compressive } \\
\text { strength of motor } \\
\text { cubes at the age of } \\
\text { 28 days }\end{array}$ & $\begin{array}{l}53.6 \\
\mathrm{MPa}\end{array}$ & $\begin{array}{l}\text { Should be more } \\
\text { than 53 MPa }\end{array}$ \\
\hline
\end{tabular}

Fine Aggregate

Natural River Sand conforming to IS: 383-1970 and IS 10262-2009 was used.The results of various tests on fine aggregate are given in Table 2. 
Table 2 Properties of Fine Aggregate

\begin{tabular}{|c|c|c|}
\hline S.No & Property & Result \\
\hline 1 & Specific gravity & 2.66 \\
\hline 2 & Fineness Modulus & 2.72 \\
\hline 3 & Grading & Zone II \\
\hline
\end{tabular}

Coarse Aggregate

Crushed granite coarse aggregate conforming to IS: 383-1970 was used. The results of various tests on coarse aggregate are given in Table 3.

Table 3 Properties of Coarse Aggregate

\begin{tabular}{|c|c|c|}
\hline S.No & Property & Result \\
\hline 1 & Specific gravity & 2.70 \\
\hline 2 & Fineness Modulus & 7.72 \\
\hline 3 & Maximum Nominal Size & $20 \mathrm{~mm}$ \\
\hline
\end{tabular}

Induction furnace slag as a fine aggregate

Induction furnace slag is an Industrial by-product of cast iron and ductile iron production. IFS used in experimental investigation from MAA MAHA MAYA INDUSTRIAL PVT LTD, Relligavaramma Peta, Vizianagaram, Andhra Pradesh, India. The properties of Induction furnace slag as Fine aggregate is give in table 4 .

Table 4 Induction furnace slag a Fine aggregate

\begin{tabular}{|c|c|c|}
\hline S.No & Property & Result \\
\hline 1 & Specific gravity & 2.86 \\
\hline 2 & Fineness Modulus & 2.55 \\
\hline 3 & Water absorption & $20 \%$ \\
\hline 4 & Bulk density & $1478.33 \mathrm{Kg} / \mathrm{cu} . \mathrm{m}$ \\
\hline
\end{tabular}

Induction furnace slag as a coarse aggregate The properties of Induction furnace slag as Coarse aggregate is give in table 5 .

Table 5 Induction furnace slag as Coarse aggregate

\begin{tabular}{|c|c|c|}
\hline S.No & Property & Result \\
\hline 1 & Specific gravity & 1.5 \\
\hline 2 & Fineness Modulus & 2.55 \\
\hline 3 & Water absorption & $20 \%$ \\
\hline 4 & Bulk density & $701.33 \mathrm{Kg} / \mathrm{cu} . \mathrm{m}$ \\
\hline
\end{tabular}

\section{Potable Water}

Ordinary potable tap water available in our laboratory was used for mixing and curing of reference concrete. It had a pH value of 7.2 .

\section{B. Mix Design -}

M25 grade of concrete mix design was carried out as per IS: $10262-2009$ and IS: 456-2000. Induction furnace slag is replaced in fine and coarse aggregate with different ratios. The mix proportions of concrete mixture are given in Table 6 .

Table 6 Mix Proportions

\begin{tabular}{|c|c|c|}
\hline S.No & Material & $\begin{array}{l}\text { M25 Grade } \\
\text { concrete per } \mathbf{~ m}^{\mathbf{3}}\end{array}$ \\
\hline 1 & Cement & $381.29 \mathrm{Kg}$ \\
\hline 2 & Fine aggregate & $0 \mathrm{Kg}$ \\
\hline 3 & $\begin{array}{c}\text { Induction furnace as a } \\
\text { Fine aggregate }\end{array}$ & $698.815 \mathrm{Kg}$ \\
\hline 4 & Coarse aggregate & $928.479 \mathrm{Kg}$ \\
\hline 5 & $\begin{array}{c}\text { Induction furnace slag } \\
\text { as a Coarse aggregate }\end{array}$ & $89.698 \mathrm{Kg}$ \\
\hline 6 & Water & $236.4 \mathrm{lt}$ \\
\hline 7 & Proportion & $1: 1.832: 2.67$ \\
\hline 8 & W/C ratio & 0.62 \\
\hline
\end{tabular}

\section{RESULTS AND DISCUSSION}

\section{A. Slump cone test -}

Slump cone test measures the workability of concrete. Slump cone test is performed as per IS: 1199-1959. The results of various percentage of replacement of IFS in fine and coarse aggregate are given in Table 7 .

Table 7 Slump values

\begin{tabular}{|c|c|c|c|}
\hline $\begin{array}{c}\text { W/C } \\
\text { Ratio }\end{array}$ & $\begin{array}{c}\text { Percentage } \\
\text { of IFS in FA }\end{array}$ & $\begin{array}{c}\text { Percentage } \\
\text { of IFS in CA }\end{array}$ & $\begin{array}{c}\text { Slump } \\
\text { in mm }\end{array}$ \\
\hline 0.62 & 100 & 0 & 98 \\
\hline 0.62 & 100 & 5 & 93 \\
\hline 0.62 & 100 & 10 & 84 \\
\hline 0.62 & 100 & 15 & 81 \\
\hline 0.62 & 100 & 20 & 78 \\
\hline
\end{tabular}

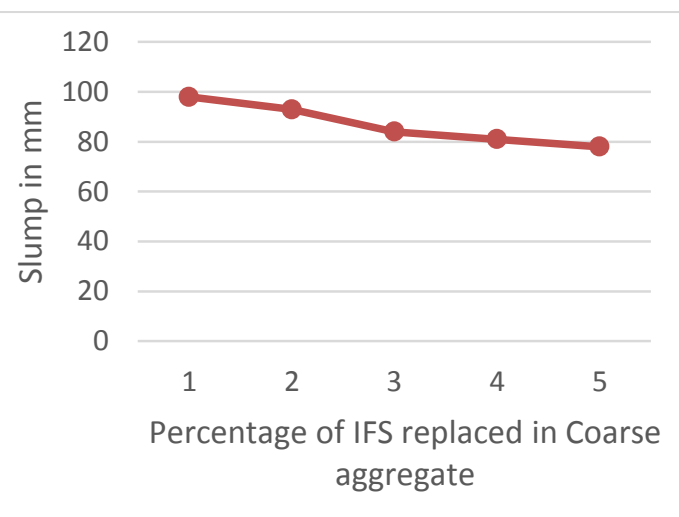

Fig 2 Slump in mm of different percentage of IFS replaced in coarse aggregate

From the above graph shows the comparison between the slump values of different percentage of induction furnace slag which is replaced in coarse aggregate. It is reported that if the percentage of 
IFS is increase in coarse aggregate content and then the workability of concrete was decreases. The value of slump in above table is varies from 75 to $100 \mathrm{~mm}$. So, the workability of above concrete is coming under medium workable.

\section{B. Compressive Strength -}

Concrete specimen cubes $150 \mathrm{~mm}$ X $150 \mathrm{~mm} \mathrm{X}$ $150 \mathrm{~mm}$ are used to determine compressive strength of concrete were tested as per IS: 5161959. The Induction furnace slag is full replaced in fine aggregate and partial replaced in coarse aggregate with different ratios. The below table shows the M25 Grade concrete mix compressive strength results with water cement ratio $0.62 \mathrm{~W} / \mathrm{C}$ ratio.

Table 8 Compressive strength in $\mathrm{MPa}$

\begin{tabular}{|c|c|c|c|}
\hline Percentage of & \multicolumn{3}{|c|}{ Compressive Strength in MPa } \\
\cline { 2 - 4 } $\begin{array}{c}\text { IFS replace in } \\
\text { CA }\end{array}$ & 3 days & $\mathbf{7}$ days & $\mathbf{2 8}$ days \\
\hline $0 \%$ & 15.36 & 18.47 & 31.55 \\
\hline $5 \%$ & 17.63 & 22.72 & 37.19 \\
\hline $10 \%$ & 19.43 & 23.85 & 39.24 \\
\hline $15 \%$ & 20.28 & 25.28 & 42.09 \\
\hline $20 \%$ & 13.83 & 22.45 & 36.19 \\
\hline
\end{tabular}

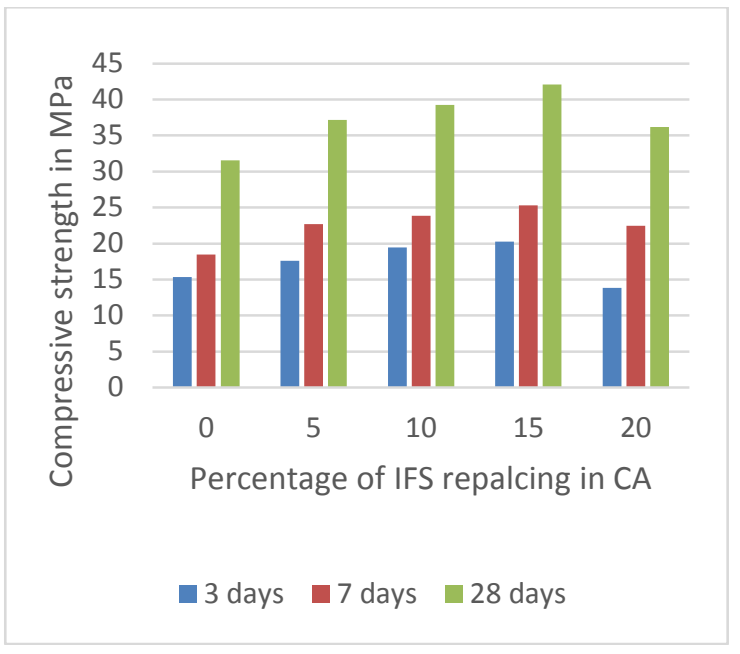

Fig 3 Compressive strength in MPa for different curing period

From the above graph shows the comparison between the compressive strength of M25 Grade concrete for various percentage of Induction furnace slag replacing in coarse aggregate at the ages of 3 days, 7 days and 28 days. It is reported that the maximum compressive strength occurs at $15 \%$ of Induction furnace slag which is replaced in coarse aggregate i.e, $20.28 \mathrm{~N} / \mathrm{mm}^{2}, 25.28 \mathrm{~N} / \mathrm{mm}^{2}$ and $42.09 \mathrm{~N} / \mathrm{mm}^{2}$ at the ages of 3 days, 7 days and 28 days respectively.

\section{Split tensile strength -}

The size of specimen $150 \mathrm{~mm}$ diameter and 300 $\mathrm{mm}$ length was used and the specimens were cured in normal water. Concrete specimen cylinders are used to determine split tensile strength of concrete and were tested as per IS: 516-1959 and IS: 58161999. The below table shows the M25 Grade concrete mix Split tensile strength results with $\mathrm{W} / \mathrm{C}$ ratio 0.62 .

Table 9 Split tensile strength in $\mathrm{MPa}$

\begin{tabular}{|c|c|c|c|}
\hline Percentage of & \multicolumn{3}{|c|}{ Split tensile Strength in MPa } \\
\cline { 2 - 4 } $\begin{array}{c}\text { IFS replace in } \\
\text { CA }\end{array}$ & 3 days & $\mathbf{7}$ days & $\mathbf{2 8}$ days \\
\hline $0 \%$ & 1.62 & 2.69 & 4.01 \\
\hline $5 \%$ & 1.71 & 2.87 & 4.28 \\
\hline $10 \%$ & 1.76 & 2.97 & 4.40 \\
\hline $15 \%$ & 1.81 & 3.05 & 4.55 \\
\hline $20 \%$ & 1.69 & 2.82 & 4.22 \\
\hline
\end{tabular}

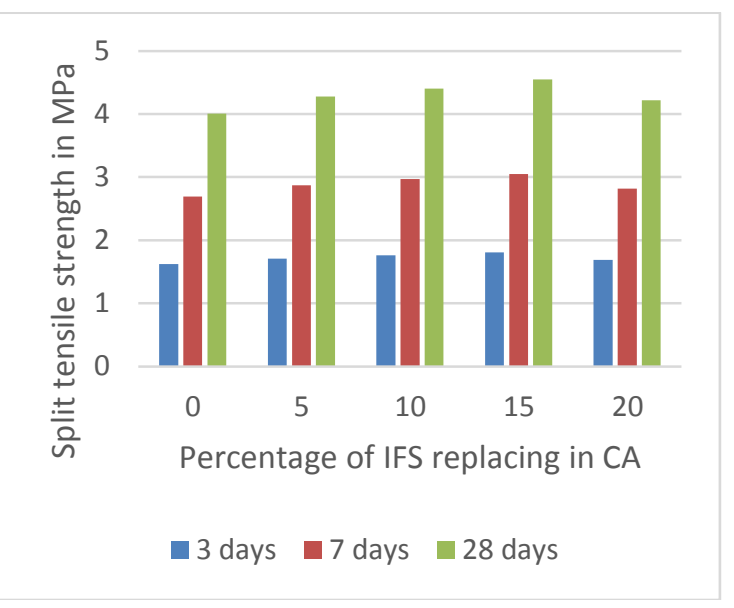

Fig 4 Split tensile strength in MPa for different curing period

From the above graph shows the comparison between the Split tensile strength of M25 Grade concrete for various percentage of Induction furnace slag replacing in coarse aggregate at the ages of 3 days, 7 days and 28 days. It is reported that at the maximum Split tensile strength occurs at $15 \%$ of Induction furnace slag which is replaced in coarse aggregate i.e, $1.81 \mathrm{~N} / \mathrm{mm}^{2}, 3.05 \mathrm{~N} / \mathrm{mm}^{2}$ and $4.55 \mathrm{~N} / \mathrm{mm}^{2}$ at the ages of 3 days, 7 days and 28 days respectively.

\section{Flexural Strength -}

Concrete specimen of size $100 \mathrm{~mm}$ X $100 \mathrm{~mm} \mathrm{X}$ $500 \mathrm{~mm}$ is used to determine flexural strength of concrete and were tested as per IS: 516-1959. The flexural strength is usually obtained experimentally by means of two point load method. The below 
table show the M25 Grade concrete mix flexural strength results with $\mathrm{W} / \mathrm{C}$ ratio 0.62 .

Table 10 Flexural strength in MPa

\begin{tabular}{|c|c|c|c|}
\hline \multirow{2}{*}{$\begin{array}{c}\text { Percentage of } \\
\text { IFS replace in } \\
\text { CA }\end{array}$} & \multicolumn{3}{|c|}{ Split tensile Strength in MPa } \\
\cline { 2 - 4 } & 3 days & $\mathbf{7}$ days & $\mathbf{2 8}$ days \\
\hline $0 \%$ & 1.69 & 2.83 & 4.22 \\
\hline $5 \%$ & 1.75 & 2.98 & 4.41 \\
\hline $10 \%$ & 1.86 & 3.11 & 4.63 \\
\hline $15 \%$ & 1.89 & 3.19 & 4.76 \\
\hline $20 \%$ & 1.76 & 2.97 & 4.43 \\
\hline
\end{tabular}

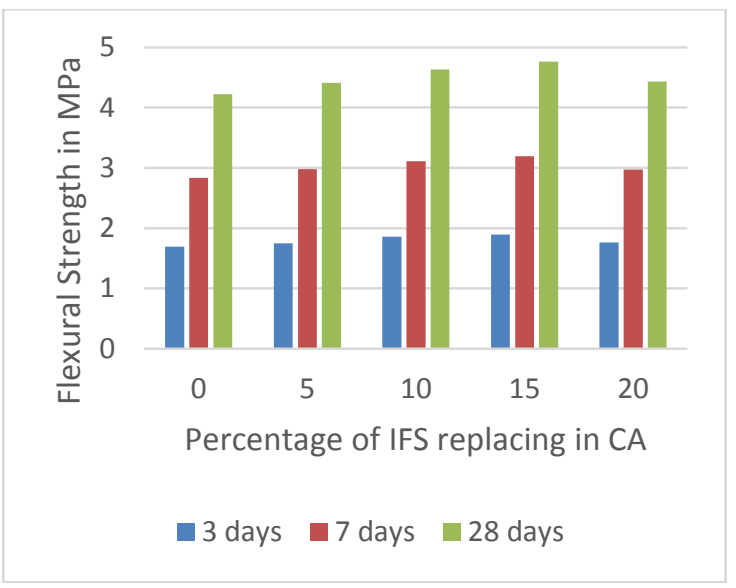

Fig 5 Flexural strength in MPa for different curing period

From the above graph shows the comparison between the flexural strength of M25 Grade concrete for various percentage of Induction furnace slag replacing in coarse aggregate at the ages of 3 days, 7 days and 28 days. It is reported that the maximum flexural strength occurs at $15 \%$ of Induction furnace slag which is replaced in coarse aggregate at i.e, $1.89 \mathrm{~N} / \mathrm{mm}^{2}, 3.19 \mathrm{~N} / \mathrm{mm}^{2}$ and $4.76 \mathrm{~N} / \mathrm{mm}^{2}$ at the ages of 3 days, 7 days and 28 days respectively.

\section{CONCLUSIONS}

Based on the experimental investigation the following conclusions are drawn

- The water absorption of Induction furnace slag as fine aggregate and as a coarse aggregate is $18.4 \%$ and $20 \%$ respectively. So, more W/C ration i.e, 0.62 is required to achieve medium workability.

- If the percentage of IFS increase in coarse aggregate content then it leads to decrease in workability. The value of slump is varies from 75 to $100 \mathrm{~mm}$.

- The maximum compressive strength i.e, $20.28 \mathrm{~N} / \mathrm{mm} 2,25.28 \mathrm{~N} / \mathrm{mm} 2$, and 42.09 $\mathrm{N} / \mathrm{mm}^{2}$ at the ages of 3 days, 7 days and
28 days respectively for M25 Grade concrete mix occurs at $15 \%$ of IFS replaced in coarse aggregate and $100 \%$ of IFS is replaced in fine aggregate.

- The Compressive strength of concrete increases up to $15 \%$ of induction furnace slag replaced in coarse aggregate and then gradually decreases the compressive strength after $15 \%$ of induction furnace slag replaced in coarse aggregate.

- The maximum Split tensile strength i.e, $1.81 \mathrm{~N} / \mathrm{mm} 2,3.05 \mathrm{~N} / \mathrm{mm} 2$, and 4.55 $\mathrm{N} / \mathrm{mm} 2$ at the ages of 3 days, 7 days and 28 days respectively for M25 Grade concrete mix occurs at $15 \%$ of IFS replaced in CA and $100 \%$ of IFS is replaced in fine aggregate.

- The Split tensile strength of concrete increases up to $15 \%$ of induction furnace slag replaced in coarse aggregate and then gradually decreases the Split tensile strength after $15 \%$ of induction furnace slag replaced in coarse aggregate.

- The maximum Flexural strength i.e, 1.89 $\mathrm{N} / \mathrm{mm} 2,3.19 \mathrm{~N} / \mathrm{mm} 2$, and $4.76 \mathrm{~N} / \mathrm{mm} 2$ for M25 Grade concrete mix occurs at $15 \%$ of Induction furnace slag replaced in coarse aggregate and $100 \%$ of induction furnace slag is replaced in fine aggregate at the ages of 3 days, 7 days and 28 days respectively.

- The flexural strength of concrete increases up to $15 \%$ of induction furnace slag replaced in coarse aggregate in coarse aggregate and then gradually decreases the flexural strength after $15 \%$ of induction furnace slag replaced in coarse aggregate.

- The split tensile strength and flexural strength of induction furnace slag concrete mix gives good results compared to conventional concrete mix because of induction furnace slag contains about 10 $15 \%$ of metals.

\section{REFERENCES}

[1]. Bassam A. Tayeh and Doha M. Al Saffar [2018], "Utilization of Waste Iron Powder as Fine Aggregate in Cement", Journal of engineering research and technology, volume 5, issue 2, june 2018.

[2]. Alsadig DY and Wagialla KM [2018], "Effect of Local Steel Slag on Compressive Strength of Cement Mortars", Journal of Advanced Chemical Engineering.

[3]. Syed Ishtiaq Ahmad and Shafiqur. Md Rahman [2018], "Mechanical and 
Durability Properties of InductionFurnace-Slag-Incorporated Recycled Aggregate Concrete", Research Article, Volume 2018.

[4]. Ramsundar. Kr and Jayanthi. R [2018], "Partial Replacement of Fine Aggregate with Iron Slag", International Journal of Innovative Research in Science, Engineering and Technology, Volume 7, Special Issue 5, April 2018.

[5]. Tarek U Mohammed, Munaz A Noor, Shibly M Apurbo, Muntasir Ahmed, Arhab Elahi and Majedul $\mathrm{H}$ Mazumder [2017], "Utilization of Induction Furnace Slag in Concrete as Coarse Aggregate", Conference Paper · February 2017.

[6]. Vijay. E, Vishal. $M$ and Mr.Vinoth Kumar. R [2017], "Experimental studies on steel slag in concrete", International Journal of Advanced Research in Civil, Structural, Environmental and Infrastructure Engineering and Developing, Volume: 3 Issue: 1 Mar, 2017.

[7]. Anil, Mukesh Kumar, Pankaj and Pardeep Kumar [2017], "Effect of Steel Slag as Partial Replacement of Fine Aggregate in M35 Grade of Concrete", Imperial Journal of Interdisciplinary Research (IJIR), Vol3, Issue-9, 2017.

[8]. Qurishee. M. A, Iqbal1. I. T, Islam. M. M and Islam. M. S [2016], "Use of slag as coarse aggregate and its effect on mechanical properties of concrete", 3rd International Conference on Advances in Civil Engineering 2016 (ICACE 2016), 21 -23 December 2016.

[9]. Mohammed Abdul Kadar. J and Dr. Dhanalakshmi. G [2016], "Experimental Investigation on Concrete by Partial Replacement on Cement by Bentonite and Coarse Aggregate by Steel Slag", International Journal of Innovative Research in Science, Engineering and Technology, Vol. 5, Issue 6, June 2016.

[10]. Prof. Pankaj Bhausaheb Autade and Hardeep Singh Jaswinder Singh Saluja [2016], "Effect of Steel Slag as a Replacement of Fine Aggregate in M40 Grade of Concrete", International Journal of New Innovations in Engineering and Technology, Volume 5 Issue 4- August 2016.

[11]. Prof. Lunagaria. M. H and Gatesi Jean De Dieu [2015], "A Study on the Compressive and Split Tensile Strength of Steel Slag Concrete Mixes for Rigid Pavement", IJSRD - International Journal for Scientific Research \& Development| Vol. 2, Issue 11, 2015.

[12]. Prof. Warudkar Abhijit A. and Mr. Nigade Y.M. [2015], "Technical Assessment on Performance of Partial Replacement of Coarse Aggregate by Steel Slag in Concrete", International Journal of Engineering Trends and Technology (IJETT) - Volume 30 Number 1 December 2015.

[13]. Gozde Inan Sezer and Mert Gulderen [2015], "Usage of steel slag in concrete as fine and/or coarse aggregate", Indian Journal of Engineering \& Material Sciences, Vol. 22, June 2015, pp. 339344.

[14]. K.Thangaselvi [2015], "Strength and Durability of Concrete Using Steel Slag as a Partial Replacement of Coarse Aggregate in Concrete", International Journal of Advanced Research Trends in Engineering and Technology (IJARTET), Vol. 2, Issue 7, July 2015.

[15]. Prem Ranjan Kumar and Dr. Pradeep Kumar T.B. [2015], "Use of Blast Furnace Slag as an Alternative of Natural Sand in Mortar and Concrete", International Journal of Innovative Research in Science, Engineering and Technology, Vol. 4, Issue 2, February 2015.

[16]. Ankush Kataria, Sonia, Rakhi and Sonia [2018], "Utilization of Steel Slag as Partial Replacement of Cement in Concrete Pavement", International Journal for Research in Applied Science \& Engineering Technology (IJRASET), Volume 6 Issue X, Oct 2018.

[17]. Sultan A. Tarawneh, Emhaidy S. Gharaibeh and Falah M. Saraireh [2014], "Effect of using steel slag aggregate on mechanical properties of concrete", American Journal of Applied Sciences 11 (5): 700-706, 2014.

[18]. Ansu John and Elson John [2013], "Study on the partial replacement of fine aggregate using induction furnace slag", American Journal of Engineering Research (AJER), Volume-4 pp-01-05.

[19]. Manjit Kaur and Mr. Sanjeev Naval [2012], "Performance of Ground Granulated Blast Furnace Slag Concrete with Partial Replacement of Sand by Saw Dust", IOSR Journal of Mechanical and Civil Engineering (IOSRJMCE), Volume 2, Issue 6 (Sep-Oct 2012), PP 26-30. 